\title{
Article
}

\section{Gender Politics and Secure Services For Women: Reflections on a study of staff understandings of challenging behaviour.}

Mckeown, M, Anderson, J, Bennett, Anthony Joseph William and Clayton, P

Available at http://clok.uclan.ac.uk/80/

Mckeown, M ORCID: 0000-0003-0235-1923, Anderson, J, Bennett, Anthony Joseph William and Clayton, P (2003) Gender Politics and Secure Services For Women: Reflections on a study of staff understandings of challenging behaviour. Journal of Psychiatric and Mental Health Nursing, 10 (5). pp. 585591. ISSN 1351-0126

It is advisable to refer to the publisher's version if you intend to cite from the work. http://dx.doi.org/10.1046/j.1365-2850.2003.00662.x

For more information about UCLan's research in this area go to http://www.uclan.ac.uk/researchgroups/ and search for <name of research Group>.

For information about Research generally at UCLan please go to http://www.uclan.ac.uk/research/

All outputs in CLoK are protected by Intellectual Property Rights law, including Copyright law. Copyright, IPR and Moral Rights for the works on this site are retained by the individual authors and/or other copyright owners. Terms and conditions for use of this material are defined in the policies page. 
Mick McKeown, Julia Anderson, Alan Bennett \& Phil Clayton. Gender Politics and Secure Services For Women: Reflections on a study of staff understandings of challenging behaviour. Journal of Psychiatric and Mental Health Nursing

\begin{abstract}
This paper discusses the findings of a Q-methodological study that investigated the complexity of professional understandings of (attitudes towards) residents in a secure unit for women with learning disabilities and challenging behaviours. Particular attention is afforded to the critical debate regarding women in psychiatric and secure care, including the significant contribution made to this literature by feminist perspectives. A multi-professional group of staff $(n=38)$ participated in the study and nine distinct accounts of women's challenging behaviour are described. Despite a considerable amount of recent policy concern with the position of women in psychiatric services, the findings of this research suggest that many front line staff are reluctant to highlight gender in their explanations of women's behaviour. This supports the assertion by Williams and colleagues (2001), who were involved in the National Gender Training Initiative (NGTI), that most critical theorizing about women's mental health has had minimal impact at the level of individuals' understandings of these important issues. This state of affairs suggests a powerful case for the expansion of staff training as provided in the NGTI, which makes gender central to understanding and emphasizes feminist perspectives.
\end{abstract}

\title{
Key Words
}

Women, Secure Services, Gender, Feminism, Politics, Q methodology 


\section{Introduction}

Psychiatric services, and forensic services in particular, have been criticized for their treatment of women and a lack of attention to important gender issues (e.g. Potier 1993, Committee of Inquiry 1992, Lloyd 1995, McKeown \& Mercer 1998, Aiyegbusi 2002). Arguably, despite a wealth of theoretical analysis of women's mental health and associated services, including important contributions from feminist perspectives, these ideas have had relatively little impact at the level of front-line care. This paper draws on the findings of a Q methodological study undertaken with staff in a secure unit for women with learning disabilities (McKeown et al, submitted for publication) to exemplify this point, and re-affirm the need for quality staff training that emphasizes the centrality of gender in understanding the position of women in secure services.

\section{Women in forensic services}

It has long since been recognised that in forensic services women are a minority group cared for in services that cater primarily for men. Criticism of services has highlighted the historical tendency to concentrate women with complex needs in the highest security facilities, where the level of security is often incommensurate with actual need (Adshead \& Morris 1995). This point has been belatedly recognised in current policy aimed at the retraction of provision for women in the High Secure Hospitals and relocation of individuals into alternative units. Reed (1992) identified women as constituting a 'special group’ of mentally disordered offender patients. This coincided with concerns expressed in the Ashworth Enquiry (Committee of Inquiry, 1992) about the unmet needs of women. Various policy statements have 
acknowledged the needs of women in mental health settings as being different to those of men. Inadequacies in the provision of services have been the focal point of discussions describing abusive and damaging experiences of women providing an argument for changes to the current system. Such criticism of mixed psychiatric facilities has indicated high rates of sexual harassment, threats and intimidation by male patients, as highlighted in the recent case of whistle-blowing at Broadmoor Special Hospital. Julie Wassell, the director of women’s services, claimed constructive dismissal from her post as a consequence of raising concerns over allegations including indecent assault and rape of women patients by their male counterparts (The Guardian 2003).

Commentators have been further concerned about identified discrepancies between men and women around admission and diagnosis. Coid and colleagues (2000) found that women are admitted to medium and high secure hospitals more often as transfers from other hospitals following non-criminalised behaviour and under the legal category psychopathic disorder. Women are also more likely to be charged with or convicted of arson and have fewer previous criminal convictions. They are more likely to receive a primary diagnosis of personality disorder than men, particularly borderline personality disorder. Coid and colleagues suggest that these differences indicate a need for new specialist therapeutic regimes for women. In a study of women at Broadmoor Hospital, Bland and colleagues (1999) also highlighted histories of sexual victimization, physical abuse and social deprivation as being significant. Acts of self harm were identified as being a greater management problem than acts of aggression towards others. The group Women in Secure Hospitals have 
contributed considerably to the debate, suggesting that women feel threatened in an environment that is male dominated.

Common practices of restraint and physical security do not take account of the therapeutic needs of women. Physical security and strict regimes are said to recreate the early experiences of women, and exacerbate feelings associated with low-self esteem, powerlessness and difficulties in establishing positive and trusting relationships (Committee of Inquiry 1992, Potier 1993, Aiyegbusi 2002). Women’s coping strategies, such as self harm, can result in labels like 'difficult to manage', particularly in lower levels of security. Consequently, women become trapped within the secure services, their detention often surpassing the average length of stay for men. Aiyegbusi (2002) has juxtaposed the fact that it is women’s challenging behaviour (rather than severity of index offence) that more often than not explains their disposal in forensic institutions, with an absence of clearly worked out formulations which might help make sense of this behaviour.

Various policy statements, including elements of Modernising Mental Health Services (DoH 1998) and the National Service Framework for Mental Health (DoH 1999) in conjunction with Safety, Privacy And Dignity In Mental Health Units (NHSE 1999) have begun to identify the changes that will be necessary to redress some of these issues. National standards, performance indicators and defined service models have provided guidance that Trusts are expected to follow to protect women in secure services. While these measures have undoubtedly brought about environmental changes, wider cultural issues in relation to gender are still a cause for concern. Women’s Mental Health: Into the Mainstream (a strategic development of mental 
health care for women) was recently published by the Department of Health (date) as a consultation document. This document attempts to outline the future of mental health services for women by addressing the social factors that impress significantly upon their lives.

\section{Making sense of the treatment of women in psychiatry}

In contrast to secure services, where women are in a minority, psychiatric services generally are typified by a disproportionate over-representation of women compared with men. Indeed, this fact has caused Allen (1986) to remark upon the irony of psychiatric textbooks typically referring to 'the patient' as male, when in reality the psychiatric patient is most usually female. Many feminist scholars have used this over-representation as a point of departure for a wider critique of gendered social relations within psychiatric practice (Busfield, 1996). More often than not this criticism focuses upon women's encounter with typically male clinicians who allegedly view their mental distress differently than they would do so if considering the complaints of an adult male. Pilgrim and Rogers (1999) point out that such sexist practices are not necessarily dependent upon male dominance within the ranks of the psychiatric profession, but may be explicable in terms of patriarchal biases irrespective of the gender of individual practitioners. These might be seen in forms of knowledge and diagnostic categories employed, or be evident in wider working practices.

In this sense, women are constructed as 'other' in contrast to male 'normality'; irrational as opposed to rational, with the feminine often also associated with intellectual inferiority. This is apparent in nineteenth century views of difference 
between men and women, seen as having a biological basis, through the operation of twentieth century theorising in the control and regulation of women's behaviour. Patterns of treatment occur where women are much more likely than men to be prescribed psychotropic medication and ECT. Other critiques (see Chesler 1972, Masson 1990) have argued that the psychiatric system goes beyond gender bias in the allocation of diagnosis and treatment, and that women are subject to abuse from male therapists.

Feminist commentators on the position of women in psychiatry have offered theoretical explanations which explore the intersection of notions of gender and mental disorder. In her groundbreaking text Women and Madness, Phylis Chesler (1972) asserted that the diagnosis of madness would be applied to women whose behaviour was viewed as a departure from expected sex roles. In this scenario, the ideal state of adult mental health is strongly associated with a male stereotype. Women become doubly disadvantaged in that both adherence to and deviance from feminine roles lead to diagnosis of mental disorder. Chesler's theoretical position was influenced by the anti-psychiatry movement, and emphasizes the social control function of mental health services (Busfield 1996). In this sense, the psychiatric enterprise is concerned with the regulation of male and female roles, attempting to ensure conformity to norms of behaviour.

Such frameworks for understanding the workings of the psychiatric system are located in a wider feminist critique of social relations in general. There is a powerful argument that patriarchal society maintains an especially invidious construct of femininity which casts men as active and women as passive. This is a world in which 
men do, and women are done to; men act, and things happen to women. This tends to be linked to a view of women as 'helpless victims of their own biology' (Allen 1987: 28). It is a short step from here to the stereotype of men as independent, rational thinkers, in control of their emotions, with women characterized alternately as overemotional, and hence, irrational beings (Busfield 1996).

Hilary Allen (1987) analysed court proceedings to show how such factors are influential in the observed tendency for more women than men to be subject to psychiatric disposal via the judicial process. Those women who commit serious crimes are then doubly deviant, transgressing both norms of civil behaviour and notions of femininity. Allen (1986), however, argues that the radical feminist accounts of psychiatry, such as that furnished by Chesler, are over-simplistic and possibly damaging to the goals of reforming the indisputably oppressive aspects of psychiatric practice and institutions.

\section{The impact of feminist theory on practice}

For Allen (1986), a feminist politics of psychiatry does not have to adhere to the idea that all of psychiatry is constituted to the singular purpose of maintaining unequal gender roles on behalf of society. Rather, there is a need for feminist practice, regardless of whether women are inherently more vulnerable to develop mental disorder, or whether the psychopathology of women can be explained in terms of ideological or material oppression. Clearly, in a context most likely typified by a complexity of possible theoretical understandings and heterogeneity of practice, there is ample room for feminist theory to influence the organization of psychiatry 
generally, and psychiatric institutions specifically, and the working culture and practice of individual staff and teams.

Notwithstanding this, the theoretical debate surrounding gender and psychiatry has largely been an abstract affair, with very little evidence of an impact upon practice generally, or secure services in particular. Various practitioners have described and promoted therapeutic approaches grounded in feminism (see Barnes \& Maple 1992, Burstow 1992), and Burman (1994) has argued for feminist research. For Worell and Remer (1992) feminist therapy is typified by:

- A recognition of the politics of gender as a central concern

- Valuing of women's knowledge and experiences

- Equality goals for individuals in therapy

- Acknowledgement that neither science nor clinical practice is value free - Active commitment to transformative social and political change.

Various authors have bemoaned the lack of interest in feminist analyses in the field of forensic clinical psychology, despite this context being rich for the applied study of gender differences (Burns date, Williams et al 2001). Others have attempted to implement and evaluate feminist therapies in secure settings (see Liebling \& Chipchase 2000). More usually, however, psychotherapy resources are spread thinly and a response to the complex needs of women can be a branding of them as 'difficult' patients (Williams et al 2001). Despite the prioritising of research into women and their needs within forensic services, there has been relatively little systematic inquiry into how staff make sense of women’s behaviour in secure settings. 
Taken together, the lack of attention to appropriate theory, therapy and research suggests a powerful need for staff training programmes to address gender as an organising theme. For these reasons a National Gender Training Initiative for staff in secure services was established (Parry-Crooke 2001). This training focuses on the centrality of gender issues in the care of women in secure environments and relevant critical reflection on practice.

\section{Our study}

We undertook a Q methodological study of multi-disciplinary team members’ accounts of women's challenging behaviour, reported in greater detail elsewhere (McKeown et al submitted for publication). Q methodology (Stephenson 1935, Brown 1980) is essentially a pattern-analytic method that has utility in the study of human subjectivity, especially how people make sense of complex issues. The approach involves participants acting upon a given pack of statement items, salient to the subject in question, which they are requested to sort into a specific grid pattern corresponding to levels of agreement or disagreement. The resulting configurations of statements, or Q sorts, are subject to mathematical techniques of rotation and factor analysis, enabling the delineation of best-fit patterns of distinct but different sorting. These 'prototypical' configurations can be read as exemplifying various separate accounts of the subject matter.

Social constructionist researchers working in the UK suggest that this material can be interpreted in terms of accessing the way in which individuals or groups draw upon available discourse to explain or articulate their understanding of particular events or 
experiences, rather than identifying the accounts as simple attitudes, belonging exclusively to individuals (Stainton Rogers, 1995). Rather, the accounts are seen as external, but available to be drawn on by individuals at any time. People can then be seen as accessing the available discourse, consistently or inconsistently over time, but always dynamically, as the ways in which they choose to express themselves might or might not change, or in response to changing relationships, circumstances or influences. For this reason it is not usual in the reporting of such Q studies to present the various accounts in terms of how many of the participants were associated with each of them. If the participant sample is sufficiently diverse and the construction of the Q pack sufficiently rigorous, then the available diversity of expression contained in the eventual Q sorts will be maximised. This should correspond to the available diversity of discourse on the respective subject matter.

A purposive sample of staff were drawn from the workforce of a secure unit for women with learning disabilities $(n=38)$ who completed a 67 item Q sort. This was constructed of statements that could be ranked in terms of their relevance to how the participants understood, or made sense of, women's challenging behaviour. Analytically, we were concerned with the importance of the narrative accounts which staff draw upon to make sense of their practice in the context of working with women who display so-called challenging behaviours, including self-harm, aggression and violence. The notion of gender was an important focus for this research, and was represented amongst the various statement items. Nine distinct accounts were articulated by the participants (see Figure 1), yet gender figured minimally in most of these, or was rejected as unimportant. This would seem to lend support to Williams 
and colleagues' (2001) assertion that relevant theory does not make an impact at grass-roots level.

\section{Gender, Feminism and Secure Services for Women.}

We believe our study is interesting in that it confirms the sense, often anecdotally remarked upon, that despite the availability of certain theoretical accounts of women in psychiatry, and secure services in particular, to advance understanding and possibly inform therapeutic approaches or general staff conduct, these have failed abjectly to intrude into the complex ways in which staff make sense of the care of women in such settings. This would suggest that these feminist or gender based accounts are subordinate to, or squeezed out by, other available discourse in secure hospitals and society generally. Such an analysis is compatible with constructionist ideas to the effect that dominant or powerful discourses operate to delimit or close down alternative ways of looking at things. Feminists would undoubtedly argue that the dominant view of women and their social position is typified by patriarchal discourse and associated power relations, and the findings of our study, are, in this sense, relatively unsurprising.

For Foucault (1988), such dominant accounts are more than mere descriptions of subjectivity, and implicitly and indivisibly involve the exercise of power. The corollary of this knowledge-power nexus is that for every powerful discourse there has to be resistance to it. Here, we might see the possibilities of accounts of events and circumstances in secure settings that emphasise gender constituting just such a resistive set of discourses and practices. The expansion of relevant staff training, as exemplified in the National Gender Training Initiative, is evidence of this, as is the 
growing attention to placing gender at the centre of particular therapeutic approaches, including feminist therapies, and the long overdue retraction of women's services in the High Secure Hospitals.

Though all of these developments are to be welcomed, the task of chnaging forensic care for women is as much about transformative and radical politics in wider society as achievements in redesign of service configurations and staff training.

\section{Acknowledgement}

This project was supported by a bursary from the National Forensic Nurses Research and Development Group awarded to Julia Anderson. 


\section{References}

Adshead G \& Morris F (1995) Another time, another place. Health Service Journal, 9 February, 24-6

Aiyegbusi, A. (2002) Nursing interventions and future directions with women in secure services.

Allen H (1986) Psychiatry and the construction of the feminine. In Miller P \& Rose N (eds) The power of psychiatry. Polity Press, Cambridge. pp 85-111.

Allen H (1987) Justice Unbalanced: Gender, Psychiatry and Judicial Decisions. Milton Keynes, Open University Press.

Barnes, M. \& Maple, N. (1992) Women and mental health: challenging the stereotypes. Birmingham, Venture Press.

Bland J, Mezey G \& Dolan B (1999) Special women, special needs: a descriptive study of female Special Hospital patients. Journal of Forensic Psychiatry, 10, 34-45.

Brown S (1980) Political Subjectivity. Yale University Press, New Haven CT.

Burman, E. (1994) Feminist Research. In Banister, P., Burman, E., Parker, I., Taylor, M. \& Tindall, C. (eds) Qualitative methods in psychology: a research guide. Milton Keynes, Open University Press. 
Burns, J (1992) Mad or just plain bad? Gender and the work of forensic clinical psychologists. In Ussher, J. \& Nicholson, P. (eds) Gender issues in clinical psychology. London ,Routledge, pp 107-128

Burstow, B. (1992) Radical feminist therapy. Newbury Park, Sage.

Busfield, J. (1996) Men, Women and Madness: understanding gender and mental disorder. London, Macmillan.

Chesler P (1972) Women and madness. New York, Doubleday.

Committee of Inquiry (1992) Report of the Committee of Inquiry into complaints about Ashworth Hospital. Cmnd 2028. HMSO, London.

Coid, J., Kahtan, N., Gault, S., \& Jarman, B. (2000) Women admitted to secure forensic psychiatry services: 1 . Comparison of women and men. The Journal of Forensic Psychiatry, 11, 275-295

Department of Health (1998) Modernising mental health services: safe, sound and supportive. London, Department of health

Department of Health (1999) National Service Framework for Mental Health. London, HMSO 
Foucault, M. (1988) Power/Knowledge: selected interviews and other writings 19721977. London, Harvester Press.

Liebling, H. \& Chipchase, H. (2000) Women who self-harm in a high security hospital. In Mercer, D., Mason, T., McKeown, M. \& McCann, G. (eds) Forensic Mental Health Care: a case study approach. Edingburgh, Churchill Livingstone. pp. 101-109.

Lloyd, A. (1995) Doubly deviant, doubly damned: society’s treatment of violent women. London, Penguin.

Masson, J. (1988) Against Therapy. London, Harper Collins.

McKeown, M. \& Mercer, D. (1998) Fallen from grace: women, power and knowledge. In Mason, T. \& Mercer, D. (eds) Critical perspectives in forensic care. Inside out. Basingstoke, Macmillan. pp 209-229.

McKeown, M., Anderson, J., Bennett, A. \& Clayton, P. (submitted for publication) 'Bad Girls' and other stories: how staff make sense of challenging behaviour in a secure unit for women. Journal of Advanced Nursing.

National Health Service Executive (1999) Safety, Privacy and Dignity in Mental Health Units London, Department of Health 
Parry-Crooke G (2001) An evaluation of working with women with mental health needs. University of North London, London.

Pilgrim D. \& Rogers, A. (1999) A sociology of mental health and illness. Second Edition. Buckingham, Open University Press.

Potier M (1993) Giving evidence: women’s lives in Ashworth maximum security psychiatric hospital. Feminism \& Psychology, 3, 335-347.

Reed, J. (1992) Report of the Official Working Group in Services for People with Special Needs. London, Department of Health

Stafford, P. (1999) Defining Gender Issues: Redefining Women’s Services London

Stainton Rogers, R. (1995) Q-Methodology. In Smith, J.A., Harre, R. \& Van Langehoven, L. (eds) Rethinking Methods in Psychology. Open University Press, Buckingham.

Stephenson, W. (1935) Correlating persons instead of tests. Character and Personality, 4, 17-24.

The Guardian. Carvel, J. (2003) Broadmoor whistle-blower wins case. March 7, 15.

Williams J, Scott S, Waterhouse S (2001) Mental health services for 'difficult' women: reflections on some recent developments. Feminist Review, 68, 89-104. 
Worell, J. \& Remer, P. (1992) Feminist perspectives in therapy: an empowerment model for women. London, Wiley. 
Figure 1. Results of the Q Study

\begin{tabular}{|c|c|c|}
\hline Account & Main Features & Summary \\
\hline $\begin{array}{l}\text { A: } \\
\text { Locating } \\
\text { problems } \\
\text { in the } \\
\text { individual }\end{array}$ & 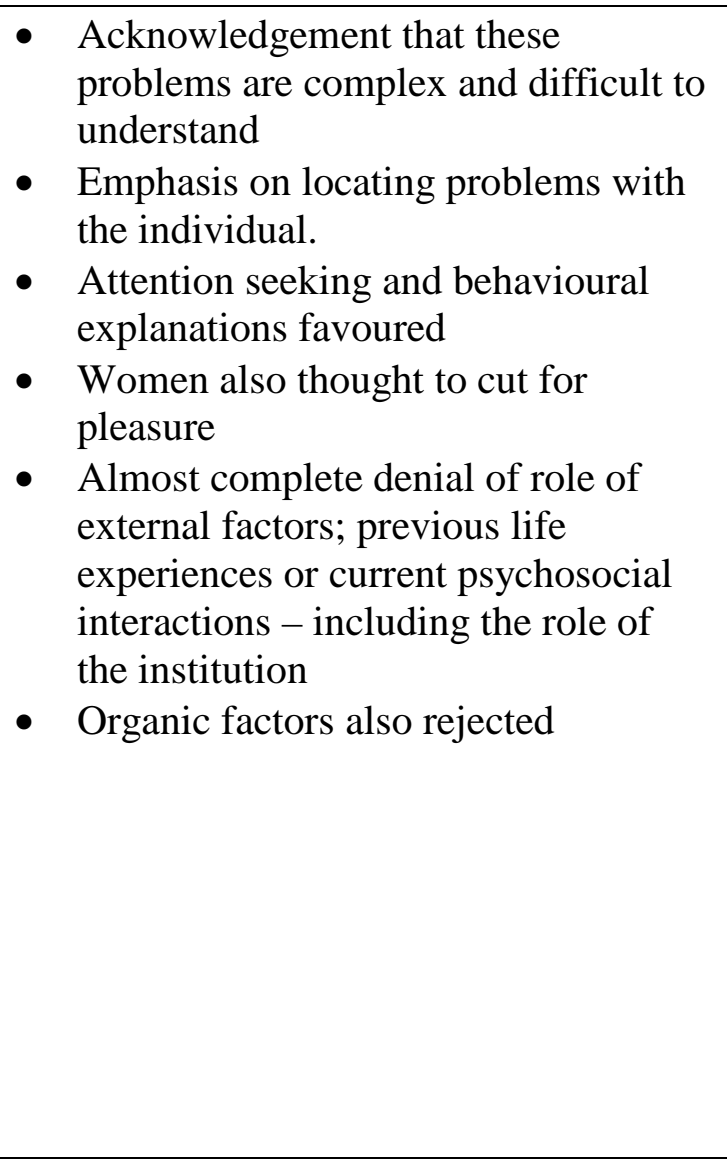 & $\begin{array}{l}\text { Women depicted in } \\
\text { terms of problematic } \\
\text { behaviours. This } \\
\text { account lacks any } \\
\text { engagement with } \\
\text { clinical theories, } \\
\text { leading to some } \\
\text { contradictions. For } \\
\text { instance, learnt } \\
\text { behaviour is } \\
\text { emphasised but there is } \\
\text { a denial of the possible } \\
\text { influence on learning of } \\
\text { various potentially } \\
\text { disruptive factors. In } \\
\text { tune with a populist } \\
\text { public representation of } \\
\text { individuals and criminal } \\
\text { responsibility: } \\
\text { Individuals are defined } \\
\text { in terms of their } \\
\text { behaviour. For this, the } \\
\text { individual is blamed } \\
\text { without mitigation. }\end{array}$ \\
\hline $\begin{array}{l}\text { B: } \\
\text { Positively } \\
\text { therapeutic }\end{array}$ & $\begin{array}{l}\text { - Confident expression of viewpoint - } \\
\text { complexity of problems does not defy } \\
\text { understanding } \\
\text { - Critical of secure services as } \\
\text { containment rather than therapy } \\
\text { Women's problems seen as } \\
\text { developmental and associated with } \\
\text { previous life experiences, which may } \\
\text { be exacerbated by aspects of secure } \\
\text { care } \\
\text { Denial that women's behaviour is } \\
\text { essentially bad or motivated to cause } \\
\text { disruption or get others into trouble } \\
\text { Psychosocial factors are emphasised, } \\
\text { but the idea that staff may have a } \\
\text { role in the genesis of problem } \\
\text { behaviour is rejected }\end{array}$ & $\begin{array}{l}\text { A generally positive, } \\
\text { therapeutically } \\
\text { orientated account. } \\
\text { Clinically informed } \\
\text { explanatory } \\
\text { frameworks are } \\
\text { stressed, with some } \\
\text { feminist inspired } \\
\text { criticism of secure } \\
\text { services. With the staff } \\
\text { holding a positive view } \\
\text { of women clients they } \\
\text { are reluctant to consider } \\
\text { any negative personal } \\
\text { role in the causation of } \\
\text { problems. In part, this } \\
\text { is contradictory of the } \\
\text { favoured psychosocial } \\
\text { elements. }\end{array}$ \\
\hline $\begin{array}{l}\text { C: } \\
\text { 'Bad girls', } \\
\text { made }\end{array}$ & $\begin{array}{l}\text { - Women patients are more of a } \\
\text { problem than men } \\
\text { - Acknowledgement that their needs }\end{array}$ & $\begin{array}{l}\text { Here gendered items } \\
\text { are prominent. Though } \\
\text { the women are blamed, }\end{array}$ \\
\hline
\end{tabular}




\begin{tabular}{|c|c|c|}
\hline worse & $\begin{array}{l}\text { are not being met } \\
\text { Women are both knowing } \\
\text { manipulators of the system and } \\
\text { damaged by the system } \\
\text { - Women's problems made worse by } \\
\text { the institution, though this is there to } \\
\text { help; practices can replicate previous } \\
\text { abuse. }\end{array}$ & $\begin{array}{l}\text { they are also } \\
\text { understood. Women are } \\
\text { identified with } \\
\text { challenging needs and } \\
\text { cause services more } \\
\text { problems. The service } \\
\text { context, including staff } \\
\text { interactions, exacerbate } \\
\text { this. The system is } \\
\text { damaging for the } \\
\text { women, who } \\
\text { consequently try to } \\
\text { manipulate } \\
\text { circumstances to their } \\
\text { advantage. }\end{array}$ \\
\hline $\begin{array}{l}\text { D: } \\
\text { Defending } \\
\text { the } \\
\text { institution }\end{array}$ & $\begin{array}{l}\text { - Women seen as more difficult than } \\
\text { men } \\
\text { - } \quad \text { Institutional factors rejected } \\
\text { - Complex mixture of explanations } \\
\text { with some contradictions } \\
\text { - Some prominence for biological } \\
\text { factors; including hormones \& } \\
\text { learning disability } \\
\text { - Self harm as a public statement about } \\
\text { relationships } \\
\text { Designed to damage relationship with } \\
\text { staff }\end{array}$ & $\begin{array}{l}\text { Despite a clear gender } \\
\text { flavour to this account, } \\
\text { any sense that social } \\
\text { inequalities or gendered } \\
\text { social relations might } \\
\text { help explain women's } \\
\text { psychological distress } \\
\text { is discounted. } \\
\text { Challenging behaviour } \\
\text { causes great difficulties } \\
\text { for the institution, but } \\
\text { no staff or institutional } \\
\text { factors are seen to be } \\
\text { part of the cause. }\end{array}$ \\
\hline $\begin{array}{l}\text { E: } \\
\text { The } \\
\text { irrelevance } \\
\text { of gender }\end{array}$ & $\begin{array}{l}\text { - Women more difficult than men } \\
\text { - Complex set of explanations yet the } \\
\text { idea that such complexity defies } \\
\text { understanding is rejected } \\
\text { - Essential differences between men } \\
\text { and women are rejected } \\
\text { - Gender as an explanatory device is } \\
\text { strongly disavowed } \\
\text { - Denial of institutional contribution } \\
\text { again evident }\end{array}$ & $\begin{array}{l}\text { There is no room here } \\
\text { to understand the } \\
\text { women's behaviour in } \\
\text { terms of gender. Some } \\
\text { non-gendered } \\
\text { biological factors, in } \\
\text { conjunction with other } \\
\text { factors, are evident, } \\
\text { within a complex } \\
\text { account of } \\
\text { psychopathology. } \\
\text { Forms of difference, } \\
\text { innate or arising from } \\
\text { social disadvantage, are } \\
\text { disavowed. But as } \\
\text { patients women are } \\
\text { viewed as a greater } \\
\text { management problem } \\
\text { than men, because of a } \\
\text { complex of biological } \\
\text { and psychosocial }\end{array}$ \\
\hline
\end{tabular}




\begin{tabular}{|c|c|c|}
\hline & & factors \\
\hline $\begin{array}{l}\text { F: } \\
\text { Women } \\
\text { are } \\
\text { different }\end{array}$ & $\begin{array}{l}\text { - Women are not more difficult than } \\
\text { men ... } \\
\text {... but are innately different } \\
\text { emotionally } \\
\text { - Heavy emphasis on psychosocial } \\
\text { factors, family influences, previous } \\
\text { abuse } \\
\text { - Biological factors also prominent } \\
\text { - Benign institution }\end{array}$ & $\begin{array}{l}\text { A bio-psychosocial } \\
\text { account of problem } \\
\text { behaviour, wherein } \\
\text { certain innate sex } \\
\text { differences between } \\
\text { men and women are } \\
\text { suggested. This does } \\
\text { not incorporate the idea } \\
\text { that women are } \\
\text { necessarily more } \\
\text { difficult than men to } \\
\text { care for. Again, the role } \\
\text { of the institution is } \\
\text { minimised. }\end{array}$ \\
\hline $\begin{array}{l}\text { G: } \\
\text { Benign } \\
\text { institution }\end{array}$ & $\begin{array}{l}\text { - Women are more difficult than men } \\
\text { - Any statement that implicates staff is } \\
\text { rejected } \\
\text { - Statements relating to self harm are } \\
\text { prominent, and this is associated with } \\
\text { history of sexual abuse } \\
\text { - Explanations for individuals' self } \\
\text { harm include: } \\
\text { o Endorphins } \\
\text { o Psychosis } \\
\text { o Exercise of control }\end{array}$ & $\begin{array}{l}\text { This account has } \\
\text { similarities with Factor } \\
\text { D: any idea staff or } \\
\text { institutional } \\
\text { contribution to the } \\
\text { cause of problem } \\
\text { behaviours is strongly } \\
\text { disavowed. Whilst the } \\
\text { former account largely } \\
\text { blamed the women for } \\
\text { their behaviour, this } \\
\text { account offers more } \\
\text { understanding. }\end{array}$ \\
\hline $\begin{array}{l}\text { H: } \\
\text { Behaviour } \\
\text { as } \\
\text { purposeful } \\
\text { and } \\
\text { devious }\end{array}$ & $\begin{array}{l}\text { - Problem behaviour is learnt or copied } \\
\text { in the institution and has institutional } \\
\text { goals } \\
\text { - Typically to make staff's life difficult } \\
\text { or gain some advantage } \\
\text { - Secure units are about containment } \\
\text { rather than therapy } \\
\text { - Past experiences do not excuse } \\
\text { behaviour } \\
\text { - Whole range of other possible } \\
\text { explanations, including role of } \\
\text { institution, are rejected }\end{array}$ & $\begin{array}{l}\text { This account is typified } \\
\text { by a lack of sympathy } \\
\text { in explaining the } \\
\text { women's behaviour, } \\
\text { which is seen as } \\
\text { purposeful, negative, } \\
\text { and inexcusable. } \\
\text { Institutional } \\
\text { containment is } \\
\text { acknowledged, possibly } \\
\text { as the only effective } \\
\text { strategy. }\end{array}$ \\
\hline $\begin{array}{l}\text { I: } \\
\text { Trying to } \\
\text { beat the } \\
\text { system }\end{array}$ & $\begin{array}{l}\text { - Women more difficult than men and } \\
\text { use aggression to get what they want } \\
\text { - } \text { Attention seeking emphasised } \\
\text { - Women behave in challenging way to } \\
\text { get control in the institution and play } \\
\text { games with staff } \\
\text { - Various explanatory factors are }\end{array}$ & $\begin{array}{l}\text { Challenging behaviour } \\
\text { is viewed here in terms } \\
\text { of individuals trying to } \\
\text { gain control in the } \\
\text { institution. Though, the } \\
\text { institution is not felt to } \\
\text { place limits on other } \\
\text { forms of expression. In }\end{array}$ \\
\hline
\end{tabular}




\begin{tabular}{|l|l|l|}
\hline $\begin{array}{l}\text { included, though previous sexual } \\
\text { abuse is downplayed }\end{array}$ & $\begin{array}{l}\text { comparison with the } \\
\text { previous account a } \\
\text { greater attempt is made } \\
\text { to grapple with } \\
\text { complex } \\
\text { understandings of } \\
\text { behaviour, and this is } \\
\text { seen to makes some } \\
\text { sense in the context of } \\
\text { the environment and } \\
\text { circumstances. }\end{array}$ \\
\hline
\end{tabular}

